\title{
TOLERANCE, UNDERSTANDING, AND RELIGIOUS TEACHING AND LEARNING IN MINORITY MUSLIM OF MANADO NORTH SULAWESI
}

\author{
Ismail Suardi Wekke*, Sabil Mokodenseho ${ }^{* *}$ \\ *Sekolah Tingi Agama Islam Negeri (STAIN) Sorong, West Papua, Indonesia \\ *** Institut Agama Islam Negeri Manado (IAIN), North Sulawesi, Indonesia \\ Email: iswekke@gmail.com \\ Presented in \\ International Seminar on Islamic and Arabic Education in Southeast Asia \\ Universitas Muhamamdiyah Malang \\ Malang, February 3-4, 2017
}

\begin{abstract}
Tolerance is the pillar in society life, but it has ambivalent power manifested in two forms are solid and democratic forms. Therefore, it is a need to explore the parctical reliious learning. The Manado city is a location where muslim is minority. This condition reflects that there is encounter between religions and faiths. This paper was conducted in State Senior High School 9 of Manado, North Sulawesi. The study shows that tolerance invites dialogs to communicate the existence of mutual recognition. Being tolerant is letting or permitting others to be themselves, respecting for others regardless of their origins and their backgrounds. Learning material was developed by the teacher accordingly to the subject in which the teacher should give a concept to the students about tolerance is required in a community consisting of various religions. Finally, this paper concludes the description of tolerance in solid form on minority muslim.
\end{abstract}

Keywords: learning material, public school, minority muslim

\section{INTRODUCTION}

Religion teaches tranquility, harmony and peace, as well as, obviously emerges positive synergy in religious life. But, there are conflicts, disputes and even violence often found happening because of or on behalf of religion (Fominaya et al., 2017; Gearon, 2010; Gurbuz \& Bernstein, 2012). Even the more troubling trend is that the conflicts are happening between members of religions which have various sects (Davidson \& Pyle, 2012; Davis, 2010). This was emerging amid the condition of the nation which was confronted by problems and protracted crises in the various fields of life, including crisis in education world. Whereas peace is all humans' desires (Charsley \& Bolognani, 2016; Craig, 2011). Chaos which often happens between religious communities was caused by the lack of religious awareness. For instance the conflict happening in Yogyakarta between Pragolan Islamic residents and Christian newcomers and Makassar (Wekke \& Lubis, 2016; Yusuf \& Wekke, 2015), Papua (Wekke, 2015). The rural atmosphere that was previously relatively strong gradually, after the coming of Christian newcomers, changed into urban atmosphere which tended to be individualists and more hectic in economic orientation rather than social life. 
Violence is happening continuously, started from vertical problems but then intersected with horizontal issues which, in this term, were issues of ethnicity and religion. Another example is the case of Ketapang which started from the dispute between thugs and locals and continued to be conflict between Christian Ambonese people and Islamic Javanese people. It began by stoning masjids and continued by ripostes by burning stores and places of worship (churches). All these chases between religious communities did not necessarily happen if they could respect each other and respect their freedom as well as aware of that the differences were not an obstacle in realizing the brotherhood between them (de Muynck, Vos, Hoogland, \& Van der Stoep, 2017; DiSalvo \& Copulsky, 2009; Elbasani \& Roy, 2017; Farrell, 2014; Mokodenseho, \& Wekke, 2017). This paper would identify religious relationship in Islamic Lesson in Public Senior High School 9 of Manado.

\section{RESEARCH METHOD}

This research applied qualitative approach. Data appointed were not in numeric form but taken from interview texts and field notes, so that the objectives of this qualitative research was to describe empirical reality behind the phenomenon in deep, detailed and completed manners (Johansson, Risberg, \& Hamberg, 2003; Molasso, 2006; Reeves, Peller, Goldman, \& Kitto, 2013). Furthermore, this use of qualitative approach was done by comparing empirical reality by applied theory using descriptive method. The qualitative research method used was naturalistic research which was done in natural condition (Hallberg, 2008; Holloway \& Todres, 2007). This research was done for approximately two (2) months, started from July 2016 until August 2016 in State Senior High School 9 of Manado, the District of Malalayang, Manado City, North Sulawesi. It was done based on a consideration that the school had typical characteristics which were in accordance with problems observed. Data collection was performed using 2 methods were interview and observation. Interviews were conducted using same questions to 18 respondents consisting of one teacher of Islamic religious lesson, one teacher of Christian religious lesson, one teacher of Catholic religious lesson, five Islamic students, five Christian students and five Catholic students.

\section{FINDINGS AND DISCUSSION}

In relation with Islamic learning process, the most important thing should be implemented in embedding values of religious tolerance in Islamic lesson in State Senior High School 9 of Manado was material presentation. The tolerance was done by mutual 
respect and giving the freedom each other to implement their teachings of religion without any disturbance from others. The teacher should also ensure the students that the diversity of humans in term of their religions and faiths was a reality desired by Allah SWT who had given them the freedom of choosing faith of kufr. Therefore, it is not justified to coerce other to embrace Islam. Besides learning material, teacher capability to present materials about religious tolerance was also required to get the students understand the materials completely. This became a difficult problem for the teacher since the students were not only individuals with all their uniqueness, but also as social beings with various backgrounds. At least, there were three aspects distinguishing a student from others; intellectual, psychological and biological aspects. The researcher saw that in State Senior High School 9 of Manado, teachers' capability of presenting materials about religious tolerance in Islam was very good since it was supported by moderate religious concept. This can be seen when the teacher was explaining to the students about QS Yunus (10:99) and its content and hadith narrated by Bukhari which tells that when the Prophet Muhammad SAW and his companions were in a forum, a group of Jewish people carrying a dead body passed in front of them. The prophet stood up immediately to get tribute upon the dead body. One of companions said, "They are Jews, O Prophet. Aren’t they?” The Prophet said, "But they are also humans.”

Moreover, explaining about QS Yunus (10: 99) and its content and hadith describing tolerance in Islam, the teacher was also connecting it with the Constitution of 1945 Chapter X concerning Religion Paragraph 29 Verse 2 which says: "The State guarantees the freedom of each citizen to embrace their own religions and to worship according to their religious beliefs". So, it was clear that aqeedah or theological viewpoint was not human's business but Allah's. There was no compromise or tolerance in this context. But muamalah was in the context of humanity. In addition to that, the researcher also observed the embedding process of the values of religious tolerance within Islamic lesson in State Senior High School 9 of Manado, which was done by giving the students chances to follow religious lessons appropriately with their respective religions, creating learning atmosphere with religious diversity, building mutual trust among them, keeping mutual understanding each other, upholding mutual love, going deep into materials about tolerance and guiding and giving motivation to the students in doing activities relating to tolerance as by not discriminating Muslim and non-Muslim students.

Islamic education which was a sub-system of national education system was one of most effective media to generate generation which has an insight which is able to take the diversity as a part which should be appreciated constructively (Hagevi, 2014; Hjelm, 2014; 
Hoy, 2013). Therefore, which this learning atmosphere, the students were expected to be able to develop tasamuh attitude both in the school and in the society. Learning strategy used by the teachers was cooperative teaching learning in social intercourse which had various properties and be able to create pleasant atmosphere (Kazanjian \& Laurence, 2007; Ketelaar, Konig, Smit, \& Thorbjornsen, 2009; Kolås, 2015). Cooperative learning process would encourage the students to study about positive sides form their friends. In turn, they would be conditioned within the learning process where a student is studying together with others in the atmosphere containing mutual respect, tolerant and understanding each other (Lee, 2016; Lenssen, 2010).

Along with advances in technology, learning media had great influence on the development of education in schools, so that the learning tools or media should be adjusted to such advances technology. The use of media of technology made the learning process to be more effective and efficient. Not only that, the development of education in schools was increasingly changing and encouraging various efforts to change. As for the learning media used to embed values of religious tolerance in religious lessons in State Senior High School 9 of Manado were curriculum, supporting textbooks, print media, electronic media (laptop and projector), audio-visual media and internet network (Long, Fui-Hoon Nah, Eschenbrenner, \& Schoonover, 2013; Plowman, 2016).

Tolerance between various religious people was one of important issues in Islamic theological system (Alberts, 2010; Allgood, 2016; Chan \& Islam, 2015). To foster this attitude, education, mainly Islamic education, was the most appropriate way to sow the seeds of tolerance, life harmony and sincere appreciation to the reality of the diversity of culturalreligious aspect of the community. Since Islamic education was a sub-system of national education which was the most effective medium to generate a generation having an insight that is able to make the diversity to be a part which should be appreciated constructively.

\section{CONCLUSION}

Indonesia is a country with very various backgrounds. Due to this, possibility of interethnic or inter-religious people conflicts is rather high in several areas. The Government's role in this term, until now, has not been appropriately done to manage conflicts, both using political and legal approaches which are partial approaches which have potential to create new problems emerging from people dissatisfaction with court rulings. Religious lesson is one of appropriate solutions to solve protracted conflicts due to its role as social 
reconstruction agent. On the other hand, teacher should consider to methods used in learning process, to let the students understand completely what the teacher delivers.

In addition, facilities of educational institutions should be improved, given that the success of education is inseparable from facilities available. Moreover, teachers must be willing to transform themselves as well as possible to guide and teach by promoting the values of tolerance. The implementation of multicultural education emphasizing on the importance of the awareness of the existing diversity needs commitments of all elements of the community since all need educational paradigm reformation. The stakeholders, especially in education world, should have strong commitment and high awareness of supporting multicultural education implementation.

\section{REFERENCE}

Alberts, W. (2010). The academic study of religions and integrative religious education in Europe. British Journal of Religious Education, 32(3), 275-290.

Allgood, I. (2016). Faith and Freedom of Religion in U.S. Public Schools: Issues and Challenges Facing Teachers. Religious Education, 111(3), 270-287.

Chan, A., \& Islam, M. S. (2015). State, religion, and environmentalism: fostering social cohesion and environmental protection in Singapore. Environmental Sociology, 1(3), 177-189.

Charsley, K., \& Bolognani, M. (2016). Being a freshie is (not) cool: stigma, capital and disgust in British Pakistani stereotypes of new subcontinental migrants. Ethnic and Racial Studies, 9870(September), 1-20.

Craig, C. J. (2011). Narrative inquiry in teaching and teacher education. Narrative Inquiries into Curriculum Making in Teacher Education (Vol. 13). Emerald.

Davidson, J. D., \& Pyle, R. E. (2012). Religious Stratification in America. Research in the Sociology of Work (Vol. 23). Emerald Group Publishing Ltd.

Davis, A. (2010). Defending religious pluralism for religious education. Ethics and Education, 5(3), 189-202.

De Muynck, B., Vos, P., Hoogland, J., \& Van der Stoep, J. (2017). A Distinctive of Christian Higher Education: Educating for Vocation. Christian Higher Education, 16(1-2), 3-10.

DiSalvo, D., \& Copulsky, J. E. (2009). Faith in the Primaries. Perspectives on Political Science, 38(2), 99-106.

Elbasani, A., \& Roy, O. (2017). Governing Islam and Religious Pluralism in New Democracies. Journal of Balkan and Near Eastern Studies, 19(1), 1-3.

Farrell, F. (2014). A critical investigation of the relationship between masculinity, social justice, religious education and the neo-liberal discourse. Education + Training, 56(7), 650-662.

Fominaya, C. F., Carvalho, L., Elsadda, H., El-tamami, W., Horrillo, P., \& Nanclares, S. (2017). Life after the squares: Reflections on the consequences of the Occupy movements. Social Movement Studies, 16(2016), 1-86.

Gearon, L. (2010). Review of Inspiring faith in schools: Studies in religious education. Journal of Moral Education, 39(1), 121-123.

Gurbuz, M. E., \& Bernstein, M. (2012). "Thou Shall Not Protest!”: Multi-Institutional Politics, Strategic Nonconfrontation and Islamic Mobilizations in Turkey. Nonviolent 
Conflict and Civil Resistance (Vol. 34). Emerald Group Publishing Ltd.

Hagevi, M. (2014). Religion and the environmental opinion in 22 countries: a comparative study. International Review of Sociology, 24(1), 91-109.

Hallberg, L. (2008). Some reflections on qualitative research. International Journal of Qualitative Studies on Health and Well-Being, 3(2), 66-67.

Hjelm, T. (2014). National piety: Religious equality, freedom of religion and national identity in Finnish political discourse. Religion, 44(1), 28-45.

Holloway, I., \& Todres, L. (2007). Thinking differently: Challenges in qualitative research. International Journal of Qualitative Studies on Health and Well-Being, 2(1), 12-18.

Hoy, A. W. (2013). A reflection on the place of emotion in teaching and teacher education. Advances in Research on Teaching (Vol. 18). Emerald Group Publishing Limited.

Johansson, E. E., Risberg, G., \& Hamberg, K. (2003). Is qualitative research scientific, or merely relevant? Scandinavian Journal of Primary Health Care, 21(1), 10-14.

Kazanjian, V., \& Laurence, P. (2007). The Journey Toward Multi-faith Community on Campus: The Religious and Spiritual Life Program at Wellesley College. Journal of College and Character, 9(2).

Ketelaar, P., Konig, R., Smit, E., \& Thorbjornsen, H. (2009). In ads we trust. Religiosness as a predictor of advertising trustworthiness ans avoidance. Journal of Consumer Marketing, 32(3), 3-30.

Kolås, A. (2015). Framing the tribal: ethnic violence in Northeast India. Asian Ethnicity, 18(March), 1-16.

Lee, B. J. (2016). "It"s not paranoia when they are really out to get you': the role of conspiracy theories in the context of heightened security. Behavioral Sciences of Terrorism and Political Aggression, $0(0), 1-17$.

Lenssen, G. (2010). Practical wisdom for turbulent times: exegesis beyond historical and canonical concerns. Journal of Management Development, 29(7/8), 686-696.

Long, Y., Fui-Hoon Nah, F., Eschenbrenner, B., \& Schoonover, T. (2013). Computersupported collaborative learning: a research framework. Industrial Management \& Data Systems, 113(4), 605-623.

Mokodenseho, S., \& Wekke, I. S. (2017). Toleransi Beragama dan Pembelajaran Agama Islam. PROSIDING, 1(1), 67-75.

Molasso, W. R. (2006). Theoretical Frameworks in Qualitative Research. Journal of College and Character, 7(7), 1-2.

Plowman, L. (2016). Revisiting ethnography by proxy. International Journal of Social Research Methodology, 5579(July), 1-12.

Reeves, S., Peller, J., Goldman, J., \& Kitto, S. (2013). Ethnography in qualitative educational research: AMEE Guide No. 80. Med Teach, 35(8), 1365-79.

Wekke, I. S. (2015). Arabic Teaching and Learning: A Model from Indonesian Muslim Minority. Procedia-Social and Behavioral Sciences, 191, 286-290.

Wekke, I. S., \& Lubis, M. A. (2016). A Multicultural approach in Arabic language teaching: creating equality at Indonesian pesantren classroom life. Sosiohumanika, 1(2).

Wekke, I. S., Mokodenseho, S., \& Firdaus, F. (2017). Religious education and tolerance: learning process in high school of minority muslim Indonesia. Seminar on Transdisiplin Education, Universiti Kebangsaan Malaysia, 16-17 January.

Yusuf, M., \& Wekke, I. S. (2015). Active learning on teaching Arabic for special purpose in Indonesian Pesantren. Procedia-Social and Behavioral Sciences, 191, 137-141. 